\title{
TIME IN IGBO COSMOLOGY: THE RITUAL AND ITS VALUES
}

\author{
Anayo Benjamin Ossai \\ http://dx.doi.org/10.4314/og.v12i s1.4
}

\begin{abstract}
In this paper, the researcher has studied the Igbo idea of lunar time which is reckoned by events and activities as against the linear dimension of Euro-American time. Regrettably the European especially in the colonial era who did not grasp the Igbo calculation of time concluded that the Igbo have no idea of time. This work investigated this claim by the European and therefore argues that such expression may be erroneous because the Igbo have idea of time. Time in the Igbo cosmology is beyond clocks and watches with calibrations from 12:00 am to $11: 59 \mathrm{pm}$, it is more than Monday to Saturday or January to December, it is cyclic which influences and is influenced by visible and invisible beings calculated in day and night, market days, moon, season and weather and are marked with rituals. The study revealed that time is highly priced and like any other thing in Igboland has religious overtone.
\end{abstract}

\section{Introduction}

In a discussion between two Europeans, Captain Winterbottom and Tony Clerk in Achebe (1986), Winterbottom referred to Igbo and said "they'v no idea of time" (p.35). The interpretation of what Winterbottom said was that Igbo have no idea of time, date, month and year. We are also not unaware of the concept of time which expresses time as vague. This idea was noted by Abakare (2012) when discussing time according to St. Augustine;

Time, according to Augustine, is an elusive concept. He says that although we talk of the past, present and future, neither the past nor the future really 
exists, for the past is gone and the future is not yet, and the present is only a passing moment ... In sum, what Augustine is saying is that time is a mental phenomenon. Time exists only in the mind. (p.56).

The above assertion simply explain that time is an abstract phenomenon that exist only in the mind. The past is only what human mind can remember, the present is what the mind considers at present which can reflect the past and the future. And finally the future is the human mind in expectation. In recent time, it has been observed in some areas of Igboland that calculation of time and dates have started resulting to misunderstanding when it clashes with the Euro-American style of calculations like the issue of period of mourning for widows and widowers in some communities in Igboland.

Our argument in this paper therefore is to show that time controls the entire socio-economic and religious life of the Igbo people which is an effort in the direction to express that Igbo or Africa at large have idea of time, but unlike the European whose time is linear, Igbo perception of time is cyclical. Kalu (2002) remarked this view thus:

Using the criterion of time, the Igbo perceive the universe and event occurring there as moving in a cyclical fashion ... The repetitive movement of the sun and the moon, the unending cycle of the seasons of the year, the cyclic of plant, vegetable and even human life, all these appear to have finished the traditional mind with the perspective for time reckoning. (p.353).

Also Ekwunife (2003) corroborated Kalu and said:

Time for the Africans is reckoned in a cyclic fashion as against the linear dimension of European time. This cyclic reckoning is punctuated by events and 
activities which are charged with religious, political and cultural overtones. Thus, instead of the usual Western chronometric time, the traditional Africa think in terms of cosmogonic time, mystical time, historical time, agricultural time, seasonal time, solar time, lunar time and so on.(p.92).

Reckoning of time in the Igbo traditional view is essentially characterized by two realms; the visible and the invisible realm. Time, calendar and market days in Igbo believe system can be described as rendezvous of all the physical and spiritual beings. The physical talk and work with time and the spiritual are believed to be the determinant of time. The Igbo calendar year known as IguAro is observed by the visible, but is calculated with sun, market days and moon and marked with rituals. Market is for both the living and the spiritual beings as observed by Ufeoro (2014) when he wrote "The markets are conglomeration of human and spiritual beings. These are the participants in Igbo market setting. Muona-azuahia, mmadunaazuahia (human beings participates in the market, the spirit participate too)" (p.155). Also, Achebe (1986) noted this fact when he was explaining why Eke market in Okperi was a great market, he said:

This deity which is called Nwanyieke is an old woman. Every Eke day before cock-crow she appears in the market place with a broom in her right hand and dances round the vast open space beckoning with her broom in all direction of the earth and drawing folk from every land (p.19)

In the Igbo traditional concept, time is reckoned in an abstract terms. The Igbo man does not talk of 12 noon. Neither does he talk of Monday nor of 2013. However, Igbo man uses non concrete terms like sunset, when chicken return to roost, at cock-crow, during new yam festival last year, at the beginning of raining season two years 
ago. This shows that for the Igbo, time is reckoned with events related to the movement of the sun and the moon or in relation to events or weather surrounding the period referred to. In other words, Igbo calendar known as Iguaro is based on the cycle of the moon where each complete circle is one month calculated of twenty eight days by which thirteen moons (month) plus one extra day make up one year. This extra day according to O. Odo (personal communication, May $20^{\text {th }}, 2015$ ) is called Amaghi Aha in Obollo of Nsukka cultural area of Igboland. By this calculation therefore 365 days make Igbo year.

\section{Categorization of Time in Igboland}

The Igbo cultural group reckons time in two categories which are the human and the ecological times. The human time is also of two spheres, the individual and the collective/community times. The individual human time is the transitional and social moments of man's life span; birth, puberty, initiation, marriage, title taking, death, burial and funeral. The collective/community time are moments marked by the community collectively like new yam festival, masquerade outing, deity ritual and so on.The ecological time is related to different seasons which are backed up with religious activities. Kalu (2002) observed these periods, "for example, іzитио (ritual week), onwaolu (period of faming), onwairiji (the yam festival period). Additionally, different localities have specific terms and phrases for individual events which provide further basis for various time calculations. (p.353).

The cyclical of life and activities in traditional Igbo communities as observed in the communal ritual and the fact that most traditional Igbo people are famers are the determinant of community/collective time in Igboland. For instance, new yam feast in Ezimo community in Nsukka cultural area of Igboland known as Ejokike is carried out at the period when the new yam is mature for harvesting. They also hold the Akatakpa and Echericha masquerades outing in the dry season. Research shows that the choice of dry 
season are for two major reasons, first, rainy season is not good for masquerade because rainfall destroys the built of masks and equally rain makes the masks uncomfortable for the spirit being believed to be behind the masks. Secondly, it is better for dry season as that is the period for less agricultural works. Men, women and children have less work in their farms and therefore create chance for recreational activities like watching and celebration of masquerades.

\section{Relevance of Igbo Time}

Investigations have revealed that time in Igboland has its origin in ritual, symbol, and spiritual forces of market days. Mythology expression claimed that spirit gave the Igbo people knowledge of time through the revelation of market days. This implicates the fact that Igbo cosmology is deeply a religious one which includes the concept of time. The relevance expresses the facts that time in Igboland controls the religious and socio-economic life of Igbo people.

\section{Religious Relevance}

The Igbo concept of time is not only a physical phenomenon, but also spiritual which is an important element of Igbo traditional religion. This belief occupies a significant place in the understanding of the role of the Igbo traditional religion in ensuring the ideal of harmonious living among the Igbo people. One ought to understand this concept to be able to appreciate how it helps the people to realize a harmonious horizontal and vertical relationship in the Igbo traditional society.

It is based on this belief system that Igbo people despite their system of time reckoning which is not definite like the EuroAmerican, but still they honestly adhere to it. The adherence is as a result of people's belief that the invisible beings keep time with them and are also present with them at all times. This belief of the presence of the invisible beings all times makes the Igbo man to mark all times with rituals. 
It was also discovered that time in Igboland rooted in the market days are dedicated to ancestors, deities and other spiritual forces. This shows why the spiritual forces honouring has a big role to play in the reckoning of time daily. Ifesieh (1989) remarked this honouring of ancestors and other spiritual forces in the marking of time in Igboland when discussing IgoOfoUtutu - Morning Prayer ritual:

In Igbo traditional religion, Morning Prayer is the most important duty that the head of each family performs before undertaking anything during the day ... Then, he takes back the kolanut holding it up in his right hand. He raises it up to the sky and invoke first, God - Chineke, then touches the ground , Ala - the mother earth, then he starts invoking the following: Chineke God, the spirits NdiMmuo, the ancestors, - Nnannaa $h a$ and the forefathers. (p.111).

Also the writer observed that in the morning prayers, the officiator after mentioning the spiritual forces goes further to invoke the spiritual forces of the market days starting from the market of the day to come and eat cola, for example, Eke biataaoji - (Eke come and eat cola),Oriebiataaoji - (Orie come and eat cola).

Another writer that acknowledged that time in Igboland has religious significance is Eze (2013) when discussing IguAro in Nri, he wrote "The Nri-Igbo yearly country festival known as IguAro marked March 10, 2012 as the beginning of the $1013^{\text {th }}$ year of the Nri calendar ... The traditional time keepers in Igboland are the Priest or Dibia" (p.1).

The religious relevance of time in Igbo traditional society could be observed from the fact that parents in Igboland name and dedicate their children to the spiritual forces believed to be custodian of the market days that mark the time (that is the market day) the child was 
born. Again Ufearo (2014) hold this view when he related some Igbo names to market days and said:

People bear the personal names as Nweke, Nwoye, Nwafo and Nwakwo, for males whereas the females answer names Mgboye, Ekemma, etcetra. The names are often derived from the market day on which the child was born. It is also believed that the market day on which the child was born has much to say about the life and destiny of the child. (p.152).

The fundamental point of the above assertion is that the time a child was born can determine the name to be given to the child in Igboland. Also, it is worthy of note that Igbo traditional people believe that the time a child was born influences the destiny of the child. This was also the view of $\mathrm{O}$. Abeye (personal communication, $11^{\text {th }}$ March 2015) where he said that his present position as the AtamaOmabe - (chief priest of omabe deity) Amaogu village of Ezimo community in Nsukka cultural area of Igboland has been destined since the day he was born. According to Abaye, he was born on Eke day and being the day omabe ritual was going on at the OnuOmabe - (Omabe shrine). Then he was named after the Omabe deity "Odo". Abeye maintained that this influenced his involvement in Omabe activities from childhood which metamorphosed to his highly respected position as AtamaOmabeAmaogu.

\section{Political Relevance}

Politics and religion are fused together in Igbo traditional belief and thought. The two are joined together and influences each other in practice. The religious and political life in Igbo traditional community depends on the intricately relationship between everybody and also the belief that the invisible influences the visible. And in ensuring this relationship is the means of reckoning time in the political administration of Igbo community. 
In traditional Igbo, the individual does not and cannot exist or operate alone without the cooperation of others. They live together and share life intensely in common. For the Igbo, their existences are owned to other people like the nuclear family, extended family, community, village and even the entire town. Whatever effects individual effect all and what affect all effect individual. Mbiti (1990) summed up this and said "I am because we are, and since we are therefore I am. This is a cardinal point in the understanding of the African view of man" (p.106). One of the possible means which ensure that the Igbo traditional world achieve this community living together is their constant meetings from time to time. And these meetings are easily convened and summoned because of the way the Igbo traditional people reckon and attach meaning to the timing of meetings.

In these meetings where socio-religious and political issues are discussed, the time of gathering and deliberations shows the importance, values and urgency the people attach to it. This view was again observed by Achebe (1986) when narrating how the visitors to Ezeulu invited him to Okperi and he (Ezeulu) summoned his people for a meeting, thus:

As soon as the messenger and his escort left Ezeulu's hut to return to Okperi the chief priest sent words to the old man who beat the giant ikolo to summon the elders and ndichie to an urgent meeting at sunset ... The meeting began as fowls went to roost and continued into the night. (pp.140-141).

Ezeulu summoned the elders and ndichie for an urgent meeting immediately his visitor left. The time of the meeting was sunset which clearly explains the categories of the people expected in the meeting, they are the elders and ndichie. The elders and ndichie are men of honour who rarely had anything to do at sunset. In the traditional Igbo setting the major work at sunset was palm wine tree dressing, but the caliber of the participants in the meeting are by 
their position exempted from climbing palm trees and therefore can afford to be in the meeting till night.

Another pointer in the assertion is how Igbo people reckon time, sunset and not $4 \mathrm{pm}$ or $5 \mathrm{pm}$, also fowl goes to roost and not $6 \mathrm{pm}$ or $7 \mathrm{pm}$. Note also that the purpose of the meeting was because Ezeulu who was one of the religious and political leaders of the community was invited to Okperi which called for concern, hence urgent deliberation by elders and ndichie.

Before any decision is taken in the traditional Igbo community, meetings are fixed through any time reckoning like sunset, before afternoon palm wine dressing, after fowl goes to roost, etcetra. In such gathering the decision of the whole community are taken and they are binding in all. The people honour such decisions mainly because of their belief that the invisible take part in every meeting. This belief is because before any meeting commences, there must be cola nut which goes with prayer. During the prayer on the cola nut the spiritual forces are always beckoned to come and be part of the meeting. So on this believe nobody dares the decision taken to avoid being unleashed by the wroth of the gods.

\section{IguAro Igbo (Igbo Calendar)}

There is controversy in the Igbo year which is as a result of the calculation of months in the Igbo traditional year. It is true that Igbo uses moon for their calculation of the year, but it is a matter of concern that a particular moon may be calculated differently by different communities in Igboland. A particular moon may be Onwalbuo ( $2^{\text {nd }}$ Moon) for one community while for another community it is Onwa Ito ( $3^{\text {rd }}$ Moon). Another issue of concern is the calculation of number of months that make up the Igbo calendar year.

Igbo scholars have different views in some of the differences noted. Scholar like Achebe (1986) claimed that there are twelve months in Igbo calendar year. This observation was remarked when he talked about Ezeulu the chief priest who eats one sacred yam 
every month for the year, he said "Ezeulu went into his barn and took down one yam from the bamboo platform built specifically for the twelve sacred yams" (p.3). Also saying that it is the twelfth sacred yam that end the year and usher in the new year marked with New Yam feast in Umuaro community, he said "the New Yam Feast - 'By our reckoning,' Obiesili took up, 'the present moon is the twelfth since the last feast" (p.203). The fact in Achebe's statement that reflects twelve months in one year is because he said twelfth moon since the last new yam feast. New yam feast for the people is the beginning of the New Year, and after the feast, the priest of Ulu - Ezeulu would be eating one yam every new moon till the twelfth yam which ends the year is eaten. After the twelfth yam comes another new yam feast that begins another new year.

Ekwunife is another Igbo scholar, but with a different view from Achebe. For him Igbo traditional year is made up of ten months. Ekwunife (2003) made this remark when he wrote "the year is divided into ten major lunar months; each month being dedicated to one or more Igbo spiritual beings. (p.92). Though Ekwunife said ten major months meaning that the months are not only ten, but ten are the ones backed with ritual to the spiritual beings. This simply means that the recognized months are the ten that are religiously marked. Idigo (2012) corroborated Ekwunife that Igbo communities count only ten months marked with feasts when he wrote:

It should be noted that in every month of the year there is a feast celebrated in most communities in Igboland especially in Aguleri. They count ten months in a year and discount the first two months (January and February), which are called "OnwaNtuvu" (lost months). There are no important feasts kept. (p.11).

The idea of Ekwunife and Idigo is in line with Igbo traditional belief and thought that everything including time is interpreted religiously. Madu (2004) pointed this out that Igbo world view is a religious one 
and said; "It is in recognition of this world view which is basically a religious one that time, space and event are interpreted in religious terms" (p.38).

In another view Ufearo (2014) put up an expression that time in Igboland is calculated through the use of Igbo market days and equally that Igbo year is made up of thirteen months, thus:

The Igbo four - market days are vial tools as far as the knowledge and calibration of time in Igboland is concerned. The four - market days serve as the matrix upon which the Igbo calendar is built. Unlike the Roman calendar, the Igbo calendar has four days in a week, seven weeks in a months and thirteen months in a year. However, the over - all synchronization of the calendar in Igboland is still an object of debate. (p.156).

Corroborating Ufearo, Bamidele (2015) wrote:

The Igbo invented a calendar called Iguafo Igbo (Igbo Calendar) so as to be aware of days and years. The calendar has four market days namely Eke, Afor, Nkwo and Orie. These days make a week. In the Igbo calendar, four days make a week, seven weeks make one month and thirteen months make a year (p.1).

In a discussion with $\mathrm{O}$. Odo (personal communication, $15^{\mathrm{t}} \mathrm{h}$ May 2015 ), he said that in Obollo community of Nsukka cultural area, a year is made up of twelve or thirteen months depending on the calculation of the moon in a particular year. In Obollo, when the sixth moon ( $6^{\text {th }}$ month) appear and cola nut has not mature for plucking that particular moon is not counted as the sixth month. In this situation that moon is referred as OyiyaOnwa meaning the moon or the month postponed. When this happens, the following moon which is supposed to be the seventh moon ( $7^{\text {th }}$ month) would be 
calculated as the sixth moon $\left(6^{\text {th }}\right.$ month) which automatically adds one month to the year and therefore make that particular year thirteen months.

He equally said that the tenth moon $\left(10^{\text {th }}\right.$ month $)$ is the last moon marked with serious ritual in Obollo community. It is the moon that Obollo people perform the new yam feast known as Isi Ji. There are other moons like the eleventh, twelfth and sometimes thirteen, but they are without any religious significance. The eleventh moon is referred as OnwaMmariri meaning the moon eaten or taken by the spirit and the twelfth moon is referred as OnwaAmag Aha meaning the unnamed moon.

Igbo or Africa at large is notoriously religious. Everything in Igboland is weighed and valued in religious strength. Simply because of the fact that the eleventh and twelfth moons (months) have no religious inclination associated with them, therefore the whole two moons (months) are indifferent and worthless.

\section{Conclusion}

Our focus in this paper is to prove that Igbo people have idea and full knowledge of time earlier to the advent of Christianity and Western education in Igboland. Our efforts so far have revealed enough evidence to help understand this fact through critical study of time reckoning in Igboland. Besides, it was discovered that the moon and market days are the tools which the traditional Igbo reckon time. We want to say that the mythical revelation of the origin of market days may be the reason why time is marked with ritual in Igboland. Our reason for this is that this appears more divine. Even though it may be argued that this does not have empirical evidence, but it centres on people's belief in Igboland which interprets everything religiously.

\section{Recommendations}

The use of traditional time reckoning will serve a purpose of bringing both educated and uneducated people closer to the 
understanding the values of Igbo culture and tradition and therefore answer the call for "African Renaissance." The observance of Igbo time reckoning shall be a defense to show that Igbo man has full idea of time, month land year. Also the time reckoning has religious undertones and therefore quells the urge of every Igbo person to satisfy his religious obligations.Lunar observation is at the disposal of the traditional Igbo people especially the elders who may be uneducated or aged and may not be able to read the Euro-American calendar considering the fact that calculation of the lunar calendar does not require education. We wish to suggest that resorting to the use of traditional Igbo time reckoning should be one of the good means of finding solution to the problem of time calculation especially in areas where it clashes with Euro-American calculation resulting to misunderstanding like the issue of time calculation of mourning period for widows and widows in some communities in Igboland. 


\section{References}

Abakare, C.O. (2012). History of philosophy 2: Medieval to contemporary period. In I. Odimegwu, I. Ndianefoo, A. Agbunusi (Ed).Basic logic \& philosophy.Awka: Fab.

Achebe,C. (1986). Arrow of God. London: British Cataloguing. Bamidele, C. (2015). Seven Interesting Facts about Ancient Igbo culture. Retrieved from connectnigeria.com $>$ article $>$ on $18 / 5 / 2015$.

Ekwnife, A.N.O. (2003). Consecration in Igbo traditional religion. Enugu: Snaap.

Eze, P. (2013). Igbo Calendar and Ifluences on Igbo PeopleCulture.Retrieved from www.nairaland.com $>$ IgboCalendar on 19/5/2015.

Idigo, F.C.(2012). The dilemma of Igbo traditional religion. Enugu. Niky.

Ifesiah, E.I. (1989). Religion at the grass roots (studies in Igbo religion). Enugu: Fourth Demension.

Kalu, O.U. (2002). Igbo traditional religious system. In G.E.K.

Ofomata (Ed.) A Survey of the Igbo nation (pp.350366)Onitsha: African First.

Madu J.E. (2004). Honest to African cultural heritage. Onitsha: Coskan.

Mbiti, J.S. (1990). African religion and philosophy. London: Heinemann.

Nwokoye, C. (2008). IguarondiIgbo .Retrieved from www.onlinenigeria.com/article/ad.asp on 24/5/2015.

Ufearoh, A. (2014). Four-Market days in Igbo cosmology.In E. O. Ezenweke, (Ed.) African traditional religion, philosophy and sustainable development. (pp.143159). Joss: Fab Anieh. 